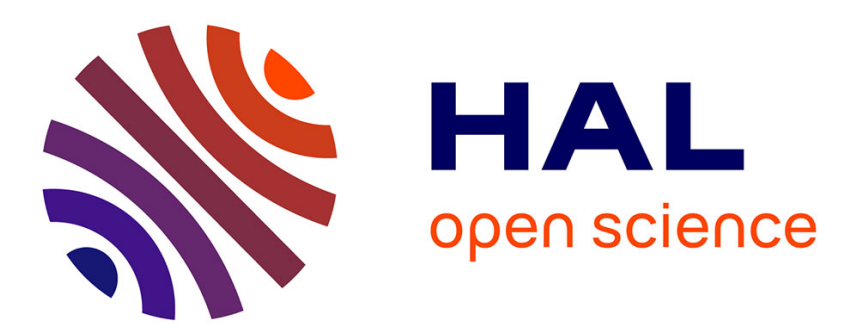

\title{
The power of the physical fabric of mudstone in creating trace fossil like redoximorphic features, case study from the late Eocene, Sirt Basin
}

Ashour Abouessa, Philippe Duringer, Jonathan Pelletier

\section{- To cite this version:}

Ashour Abouessa, Philippe Duringer, Jonathan Pelletier. The power of the physical fabric of mudstone in creating trace fossil like redoximorphic features, case study from the late Eocene, Sirt Basin. Journal of African Earth Sciences, 2020, 170, pp.103931. 10.1016/j.jafrearsci.2020.103931 . insu-02919338

\section{HAL Id: insu-02919338 \\ https://hal-insu.archives-ouvertes.fr/insu-02919338}

Submitted on 22 Aug 2020

HAL is a multi-disciplinary open access archive for the deposit and dissemination of scientific research documents, whether they are published or not. The documents may come from teaching and research institutions in France or abroad, or from public or private research centers.
L'archive ouverte pluridisciplinaire $\mathbf{H A L}$, est destinée au dépôt et à la diffusion de documents scientifiques de niveau recherche, publiés ou non, émanant des établissements d'enseignement et de recherche français ou étrangers, des laboratoires publics ou privés. 


\section{Journal Pre-proof}

The power of the physical fabric of mudstone in creating trace fossil like redoximorphic features, case study from the late Eocene, Sirt Basin

Abouessa Ashour, Duringer Philippe, Pelletier Jonathan

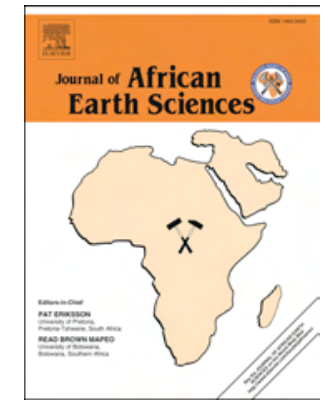

PII:

S1464-343X(20)30182-5

DOI:

https://doi.org/10.1016/j.jafrearsci.2020.103931

Reference: $\quad$ AES 103931

To appear in: Journal of African Earth Sciences

Received Date: 6 January 2020

Revised Date: 5 June 2020

Accepted Date: 9 June 2020

Please cite this article as: Ashour, A., Philippe, D., Jonathan, P., The power of the physical fabric of mudstone in creating trace fossil like redoximorphic features, case study from the late Eocene, Sirt Basin, Journal of African Earth Sciences (2020), doi: https://doi.org/10.1016/j.jafrearsci.2020.103931.

This is a PDF file of an article that has undergone enhancements after acceptance, such as the addition of a cover page and metadata, and formatting for readability, but it is not yet the definitive version of record. This version will undergo additional copyediting, typesetting and review before it is published in its final form, but we are providing this version to give early visibility of the article. Please note that, during the production process, errors may be discovered which could affect the content, and all legal disclaimers that apply to the journal pertain.

(C) 2020 Published by Elsevier Ltd. 


\title{
The power of the physical fabric of mudstone in creating trace fossil like redoximorphic features, case study from the late Eocene, Sirt Basin
}

\begin{abstract}
Abouessa Ashour $^{\mathrm{a}}$, Duringer Philippe ${ }^{\mathrm{a}}$, Pelletier Jonathan ${ }^{\mathrm{b}}$
a: Institut de Physique du Globe de Strasbourg (IPGS), UMR 7516, Université de Strasbourg (UdS), École et Observatoire des Sciences de la Terre (EOST), Centre National de la Recherche Scientifique (CNRS), Bâtiment de Géologie, 1 rue Blessig, 67084 Strasbourg Cedex, France b: TOTAL, Technical Centre, Avenue Larribau, 64018 Pau Cedex, France
\end{abstract}

\section{Abstract}

This article presents complex paleo-pedoturbation features, preserved in a massive mudstone stratum belonging to a siliciclastic sequence in the upper Eocene. The outcrop of these turbations presents an intricate network of iron oxide in semi tubular forms. The mudstone to which these structures are restricted is lithologically similar to other mudstone beds, below and above it in the sequence. In contrast, it presents more paleo-pedogenic features.

Attributing these tubular structures to a specific burrow is difficult for two reasons: the apparent similarities in morphology to numerous trace fossils coupled with the absence of diagnostic excavation-locomotion proxies, as well as the lack of any faunal or floral body fossils in the parent mudstone. Moreover, these structures do not convincingly conform to the simplified image documented in numerous publications for fossil roots.

Taking into account the exclusive, physicochemical properties of the clay rich rocks (shrinkswell behaviour, erratic permeability and cation-exchange capacity), this article provides potential evidence that such trace fossil-like features could, alternatively, be produced by abiotic redox processes without pre-existing faunal or floral predecessors. Regardless of the extent to which the provided justifications are acceptable, they might increase awareness as to just how treacherous trace fossil identification can be. The studied case draws attention to the fact that, in mudstones, the dividing line between valid and spurious trace fossils can be very subtle. It also assists in better recognition of paleosol features in mudstones.

Keywords: mudstone fabric, paleosols, redox features, trace fossils, tubular forms, Fe-oxides

\section{Introduction}

The morphological pattern of redoximorphic features in paleosols, and sedimentary rocks in general, are controlled by the pre-existence of either physical fabric or biogenic fabric. Such abiotic or biotic templates are overprinted by the accumulation of iron or other oxides to preserve the preexisting morphology. The attribution of the redoximorphic accumulation of tubular (or similar) structures to pre-existing roots or burrows became almost spontaneous because of its ubiquity. In fact, ascribing any almost-tubular morphologic features to presumed, formerly existing roots or burrows is not always correct and, thus, might cause false geological interpretations. In clay dominated strata, with their particular textural and geochemical properties, morphogenic features attributed to pre- 
existing physical textures and fabrics have received little attention and appear to have been underestimated.

The Late Eocene outcrop in the Sirt Basin (Fig. 1a) presents a case study where structures that were previously interpreted as trace fossils (Wight, 1980; Abouessa et al., 2012) might also be ascribed to physical rather than biogenic ancestors. In soils and sediments, complex Fe-oxide precipitation patterns produced by porewater/rock interactions result in morphological features that reflect the internal structures of the host rocks (Muller and Bocquier, 1986; Goldenfeld et al., 2006; Chan et al., 2007; Barge et al., 2011). The drainage capacity (permeability) of sediments is an essential controlling factor in the distribution of oxide accumulation (Gasparatos et al., 2002; Kraus and Hasiotis, 2006; Brierley et al., 2011). Accordingly, the pattern of solute circulation and deposition would strongly differ from muddy to sandy sediments, based on their drainage capacity.

In sandstones with isotropic hydraulic conductivity, redox features are initiated as simple structureless nodules that then become concretions with uniform, concentric structures (Brewer, 1964; Veneman et al., 1975; Gasparatos, 2012). Their shape is controlled by the texture of the sediments. Their precipitation is initiated around physical or biological nuclei (Allison, 1988; Allison and Duck, 1990; Trewin, 1992; Martinez, 1996; Richter et al., 2007). If physicochemical conditions allow for continuous precipitation, concretions evolve into distinctly shaped, variant and uniform, selforganising Liesegang patterns (Kessler and Werner, 2003; Wang et al., 2015). Thus, physicochemical precipitation could accumulate 'unexpectedly' variable features by overprinting the pre-existing physical fabric of the sediments. For instance, sand pipes (Thompson and Stokes, 1970) result from iron minerals precipitating out of ground water as it moves through the rock. Tubular structures of iron oxide at Rio Tinto (Barge et al., 2016) form through self-assembly via an abiotic mechanism involving templated precipitation around a fluid jet. In fact, the extent that physicochemical morphological features can reach is best given by cave deposits (speleothems and helictites) (Hinman, 1988; Aharon et al., 2006). These are precipitated on the cave walls during the seepage of water from rock into the air. Therefore, considering the highly variable temporal and spatial interactions between all textural and environmental factors, the precipitation pattern would be unexpectedly delicate.

Given that the permeability of sediments is a major factor in the passage of cation-carrying solutions, the accumulation trends will vary unevenly, even in the same sediments. In contrast to the well-organised redox features given by sandstones, mudstones would host features that reflect their particularities due to their different physicochemical properties. These properties include shrink-swell behaviour, the cation-exchange capacity (Muller and Bocquier, 1986; Smith et al., 2008; Kvoda et al., 2016), and the anisotropic "non-Darcian" permeability (Mitchell et al., 2005; Wang et al., 2018). Permeability in mudstones is very low and heterogeneous compared to that of sand and siltstones. Solute transport and precipitation in mud is more influenced by secondary permeability, such as that produced by dehydration cracks and micrograin rearrangement during the formation and alteration of 
soil peds (through pelitoclastesis) (Bouma et al., 1977; Zhang and Karathanasis, 1997; Wetzel and Einsele, 1991; Canton et al., 2001; Mondol et al., 2008; Moussavi-Harami et al., 2009).

In this succession (Fig. 1b), among many lithologically-similar mudstone strata, the studied stratum (1-2 $\mathrm{m}$ in thicknss; Fig. 1c) preserves exclusive paleo-pedogenic features. In addition to the initial redoximorphic mottling and localised Fe-oxide accumulations, pedoturbation structural forms that largely resemble the trace fossil Thalassinoides. These structures are generally presented as crowded tubular and semi-cylindrical accumulations of iron oxides. Their morphology makes it hard to exclude biogenic templates. Their architecture is, therefore, either unusually well-organised or very poorly shaped, to be ascribed to floral or faunal predecessors. In fact, there are always delicate elements that do not concord with a presumed biogenic ancestry, and other elements that support physical templates. An argument will be presented by this article. The aim is not to completely deny the trace fossil origin but to highlight an alternative interpretation that might be realistic in the case of clay-rich sediments.

\section{The geological context}

Among several massive and differently-fractured mudstone strata, the studied paleopedoturbations are restricted to, and are characteristic of, one stratum. This stratum is embedded in the upper, fluvially-dominated, part of an $80 \mathrm{~m}$ succession of thinly stratified siliciclastic rocks called the New Idam Unit (Abouessa et al., 2012). Each of the mudstone beds in this unit is $\sim 1-2 \mathrm{~m}$ thick, bearing, in most cases, erosive upper and gradational lower contacts with the sandstones. The entire unit was deposited in a regressive estuary. Marine indicators dominate the lower part of the sequence, while terrestrial indicators dominate the upper part (Wight, 1980; Abouessa et al., 2012, 2015). This fact is given by the prevalence of diagnostic biogenic indications (traces, fauna, flora) with which the New Idam Unit is exceptionally crowded (Savage, 1970; Wight, 1980; Rasmussen et al., 2008: Abouessa et al., 2012, 2015). Assemblages of sedimentary and biogenic structures, as well as fossil fauna and flora, indicate that a tropical-subtropical climate was prevailing at the time of deposition in the Late Eocene (38-39 Ma) (Jaeger et al., 2010a, b). In the sandstone strata, fossil root traces are evident and terrestrial bioturbation structures are ubiquitous. Contrastingly, in the mudstone beds, the paleo-pedogenesis is less developed, being restricted to discolouration, slickensides, shrink-swell cracks, pelitoclastesis and, possibly, roots.

The geological context indicates that the sand-siltstone beds are channel and inter-channel flat deposits. The mudstones are interpreted in the lower part of the New Idam Unit as being intertidal lagoons. This is evidenced by the embedded shallow marine molluses and the diagnostic sedimentary tidal structures (Abouessa et al., 2012, 2015). In the upper part, where the host mudstone stratum is located (Fig. 1b, c), mudstone beds are largely attributed to shallow, fresh water lakes. This is proven, 
not only by the domination of successive pedogenically-altered layers (with terrestrial fossils and trace fossils) but, also, by the complete disappearance of marine fossils.

In a broader sense, the colour of the mudstone beds in the terrestrial part lies in the spectrum of light green to light greenish-grey. The latter is the colour of the dominating matrix of the host mud, thus attesting to poor drainage conditions (e.g. Kraus, 1998). In comparison, a light bluish-green colour prevails in the lower, marine-dominated mudstones. The clay minerals forming the mudstones are predominantly kaolinite, chlorite and montmorillonite (Wight, 1980; Vasic and Sherif, 2007).

\section{Description of the host mudstone}

All of the mudstone beds, including the one hosting the studied pedoturbation, are water-lain suspension deposits (originally water-saturated). No synsedimentary structures are observed, nor are there any indications of compaction or dissolution. From one mudstone bed to another, characteristic dehydration (shrink-swell) cracks/fractures show the character of the clay-rich vertisols (e.g. Duchaufour, 1982; Kraus and Aslan, 1993; Soil Survey Staff, 1998) (Fig. 2a-h). These are of a remarkably variable intensity, dimension and orientation pattern. Mottling predominantly re-occurs as whitish, light-grey spots and patches as well as pale yellow to light brown pigmentation along joints and slickenside faces (Fig. 2d). Locally, these can also be purple and, more rarely, red. The fractures can appear to be regular and irregular, open and closed. They are millimetres to centimetres apart and up to several centimetres long. The more striking fracture orientations are vertical to subhorizontal, straight and irregular. Subordinate finer cracks, in-between the main fractures, create patterns that are variable from one site to another.

The fractures are particularly more intense in the host mudstone and are more variably oriented. Diagonal (Figs. 2h, 3a, b) and circular fractures are obvious here, compared to other mudstone beds. Interlocking cracks are common, with variable dimensions, simple and composite structures, subcircular and circular in shape. These are organised in a similar manner (Fig. 3c-e) and are better developed with increasing depth. Similar concentric cracks in mud are described in Ollier (1971) and Lakshmikantha (2009). Together with the other paleo-pedogenic processes, the influence of fracturing in the fabric of this mudstone seems overriding. Vermicular structures (Retallak, 1983) are also present (Fig. 3f).

Like the shrink-swell fractures, mottling and Fe-coatings are also more common in the host mudstone. These occur as subcircular spots and discolouration patches, ubiquitously scattered in the matrix. Among others, common lath-shaped forms are found, either in isolation or in continuity with the brown Fe-oxide cumulate (e.g., Fig. 3a, b). All of these aspects are also acknowledged as common criteria in vertisols (e.g. Driese and Foreman, 1992; Mack et al., 1993; Driese et al., 2000; Miller et al., 2010; Kovda et al., 2016). 


\section{Description of the hosted structures}

In a broad sense, the studied iron oxide turbations are exhibited as a network of reticulated and solitary, delicately and poorly shaped semi-tubular structures. Overall, they resemble the trace fossil Thalassinoides and fossil roots, to a lesser extent. They constitute finger-sized, 1-2 cm tubules and larger semi-cylindrical regular and irregular shafts, 5-15 cm in diameter (Fig. 4a, b). Small tubules are commonly a few cm long and are angularly attached together. They appear to be longer when longitudinally joined; very narrow separation cracks can occasionally be discerned. The large tubules (shafts) are up to $35 \mathrm{~cm}$ long. In an intermediate horizon, many of them are strictly parallel (Fig. 4c-f). The small tubules densely dominate, but are not restricted to, the top $30-40 \mathrm{~cm}$ horizon. The shafts are less dense in the lower part of host bed but neither penetrate the subjacent sandstone nor reach the top of the host. The two forms (tubules and shafts) interlock together (Fig. 4b, d) in the intermediate zone, 30 to $70 \mathrm{~m}$ below the top of the host bed. In addition to the (considerably defined) tubular forms, morphologically different Fe-oxide structures with angular edges and straight outlines (Fig. 5a-c), are adjacently associated.

The interior (filling) of all these structures is composed of massive muddy materials, dominated by iron oxides. The prevailing colour is brown-yellow which is indicative of goethite (Duchaufour, 1982; Schwertmann and Taylor, 1989; PiPujol and Buurman, 1994; Gasparatos et al., 2004). The overall texture is similar to the ambient sediments. The outer surfaces are smooth, knobby, and scaly, with no special textural ornamentations. There are locations in the parent mudstone where the adjacent mud fabric exhibits a fracturing pattern with identical textural and orientation aspects to that of the hosted structures (Fig. 5a-d).

The colours preserved by all the morphoforms are not restricted to brown-yellow. Pale yellow, light to dark brown and whitish grey are also incorporated. Forms preserving a patchwork of these colours are not exceptional (Figs. 4c-f; $5 \mathrm{~b}, \mathrm{~d}$ ). Structures where the colour gradually changes from whitish grey to brown or yellow are common. Abrupt colour contact with the greenish matrix seems to prevail (Fig. 5a, b). Halos of lighter colour shades surrounding larger structures are not uncommon. Notably, in many cases these halos resemble the shape and the dimensions of the adjacent tubules (Fig. 5c, d).

The cross-sectional area of the small tubules is commonly semi-circular and flattened, with their two dimensions being occasionally changeable along their long axis. Despite the organisational pattern of the network, cross-cutting between individuals is not evident, although they give the appearance of having intersected. Meeting points are dominantly angular rather than curved (Fig. 5d, e). Remarkably distinctive cross-hatched patterns (Fig. 5e) are re-occurring.

Closer to the base of the host bed, the shafts contrastingly prevail over the small tubules, which became scarce and solitary. Compared to those slightly above, the shafts here are evidently 
circular, with their outer surface (crust) having become very unevenly agglomerated and/or coarsely botryoidal (Fig. 6a, b). The interior consists of muddy materials of a greenish brown colour, grading out to dark brown at the resistant crust. Besides this, the outcrop at this location presents a common case where the interior of the shafts is composed of several smaller tubules with a circular crosssectional area, made distinctive by their internal, concentric bands (Fig. 6b, c). Smaller tubules also grow adjacently, attached (Fig. 6a, b) or detached (Fig. 6b, c) from the shafts. They may extend for a few tens of centimetres (Fig. 6d) with no change in their diameter.

\section{Discussion}

The principle aim of this chapter is to test the possibility of the pre-existence of physical, rather than biological, templates for the described redoximorphic features. With respect to the morphology alone, the hypothesis of a physical signature would seem unlikely. This is because geologists used to spontaneously attribute such a network of tubular forms to biological origins, and this was usually true. This discussion attempts to orient attention towards the influence of the physical fabric and emphasizes the role of physicochemical (abiotic) processes on the production of such trace fossil-like structures. Two lines of justification are worth examining: (i) the contradictions presented by these structures if they are of biotic origin; (ii) the extent to which abiotic physical processes can produce such figures on their own.

Firstly: considering morphology, it is almost impossible to provide solid evidence that completely refutes the former existence of burrows created by crustaceans and annelids, or roots. All of those can leave behind a similar network (e.g. Bromley and Frey, 1974; Howard and Frey, 1984; Seilacher, 2007; Hasiotis and Mitchell, 1993; Monaco, 2000; Hasiotis and Bourke, 2006; Moh et al., 2015). Apart from the morphology, these Fe-oxide structures are barren of any strict evidence of a biogenic origin. The known traits concerning the mode of preservation of roots (Klappa, 1980; Jaillard et al., 1991; Hasiotis, 2002; Kraus and Hasiotis, 2006; Genise et al., 2004; Gregory et al., 2004; Nascimento et al., 2019) is not fulfilled by those structures. Despite the good preservation of such soft sediments (Buatois and Mángano, 2004), no evident roots, moulds or casts are preserved, although they are evident in other strata, above and below. Carbonised remains of roots and central root canals are absent and secondary roots (branching/ root hairs) are not detected either. The characteristic tapering downward of root morphology cannot be considered to be evident here. Moreover, the length of the individual tubules is a few centimetres and so the length to width ratio is too large to be confidently attributed to the known burrow-making organisms, neither match with those of roots. The sharp angle of tubule attachment enhances this aspect. It seems to be too angular to be ascribed to the burrowers producing similar tubular morphology. Known evidence for burrowing organisms' locomotion, such as scratch marks and wall linings, are totally absent. 
In fact, the halos (such as the ones in Figure (5d)) that resemble the Fe-oxide tubules, could be considered as the initial step of producing these tubules away from any biological guidance. Here, the stains affect the intact, non-turbated, matrix. Such localised iron oxide precipitation in mudstones is thought to be initiated along microscopic fractures and/or in localised sites of increased permeability (Vepraskas, 1994; Driese et al., 1995; Hildenbranda and Uraib, 2003; Gasparatos et al., 2004). Refutation of faunal/floral activities preceding the iron oxide accumulation is, thus, suggested by the lack of any marks or indications of excavation and root penetration. Concerning the semi-cylindrical bodies, the angle of inclination, together with the parallelism, does not fit with that of biogenic activities. Furthermore, the texture and the internal structure of the tubules are identical to that of the ambient mudstone (Fig. 5a-d). There is no external material introduced from the superjacent sandstone.

Secondly: to what extent could abiotic physical predecessors provide the template for such Feoxide figures on their own? The essential elements in this regard are suggested by the exclusively abiotic (physical as well as chemical) paleo-pedogenic processes that eventually acted on the various mudstone beds in the succession. The network of dehydration cracks reflects the response to physical processes (Einsele, 1983; Bland and Rolls, 1998; Mondol et al., 2008). The iron oxide's pigmentation and thicker accumulations along and around the physical surfaces (e.g. Fig. 2d) are related to the chemical processes. In paleosols with similar vertic properties, these processes are related to the repeatability of wetting/drying climatic cycles (Sridharan and Allam, 1982; Canton et al., 2001; Kishné et al., 2009; Tang et al., 2011; Kovda et al., 2016) which is able to significantly alter the original fabric. Climatic conditions, in combination with the prevailing geochemical factors, are responsible for producing different soil morphologies (Brewer, 1976; Martinez, 1996; Wright, 1995; Breemen and Buurman, 2002). Accordingly, the host mudstone, compared to the other mudstone beds in the sequence, must have been subjected to relatively prolonged periods of pedogenesis that resulted in morphoforms similar to trace fossils. Rectangular rhombic, vermicular and concentric fabrics (Fig. 3) are among those physical forms that are particularly exhibited by the mudstone. The overprinting of these fabric forms is analogous to the overprinting of biogenic (faunal or floral) fabrics (Veneman et al., 1975; Vepraskas, 1994).

Based on the preserved mudstone fabric, the quadrant geometrical forms, with their sharp rectangular edges (Fig. 5a, for instance), undoubtedly attest to the physical soil fabric being overprinted. These are simply slickensided masses of mudstone, coated by goethite, concentrated along the boundaries. Similarly, the parallel (semi-cylindrical) forms are due to goethite accumulation around differently fabricated mud masses. Besides their perfect parallelism, in-depth examination reveals that most cylinders are incompletely circular. There is always one side that is straight enough to be attributed to a burrow rather than to a fracture wall, and the facing side is usually a parallel fracture that, illusively, appear as part of the cylinder (Fig. 4e). The unexcavated interior which is texturally identical to the ambient mud, supports this view. It is worth comparing the 'certain' 
cylindrical shape of the decapod trace fossil (Abouessa et al., 2015) found in the sandstone beds, both sub and superjacent to the host mudstone.

Since there is no clear Fe-source above and below the hosting bed, the iron must have been provided by the clay minerals comprising the mudstone, which are characterised by their iron content and their high cation-exchange capacity (Dasog et al., 1988; Soil Survey Staff, 1998; Manceau et al., 2000; Brierley et al., 2011; Kvoda et al., 2016). Iron removed from clay via reduction processes leaves behind whitish grey patches (Fig. 3a, b), displaced through cracks, and re-deposited at first contact with oxygenated sites (Schwertmann and Taylor, 1989; Schwertmann, 1993; Vepraskas, 1994; Beverly et al., 2018). Further growth and shaping of the iron precipitate are then controlled by the local fabric, the local permeability, and the availability of the Fe-charged solutes. Comparable cases and details about the mechanism are best illustrated in Buurman (1975), Retallack (1983), PiPujol and Buurman (1994), Drles et al. (1995), and Beverly et al. (2018).

The composite shafts, with their concentric tubules, are then explained by the concentric cracks presented by the ambient mudstone (Fig. 3c-e), which provide solute conduits as well as accumulation sites. Here, the shafts essentially overprinted the crack rings presented by the mud. Practical proof is given by the half circular accumulations, such as those shown in Figure $(7 \mathrm{a}, \mathrm{b})$ where the iron oxide precipitate has efficiently overprinted the circular cracks. The circular forms here are not complete because precipitation has stopped, either due to insufficient solution or because the precipitation had been deviated vertically in response to the imperfect drainage. Precipitation would continue preferentially vertically, along a given fracture, when impeded from lateral growth (Yuen et al., 1998; Rayhani et al., 2008; Li et al., 2009). The internal tubules, with their concentric bands, simulate the smaller circular rings. Some of them grow independently while others grow attached to the large shafts. The tendency of iron oxides precipitate to form tubular bodies (Ambrosi and Nahon, 1986; Muller and Bocquier, 1986; Gaiffe and Kubler, 1992; Sadek and Sultan, 2011; Berge et al., 2016) can be recalled for this location. This can be further 'guesstimated' by Figure (7c), where the reduction and oxidation have occurred adjacently on the fractured mudstone masses, of which the matrix is non-bioturbated. Further explanations and comparable cases are given by Brewer (1976), Arshad and Arnaud (1980), Pipujol and Buurman (1994), Vepraskas (1994) and Kessler and Werner (2003).

Concerning the networks of finger-sized tubules, they might be hardly attributable to the relatively more intense fracture networks. Nevertheless, this hypothesis might be considered acceptable, if one takes into account the fact that, at a certain stage of pedogenesis, a vermicular structure (Figs. 2g, 3f), similar to these tubes, had been fabricated by the combination of the fractures and the mud aggregation. Thus, dehydration cracks, in combination with pelitoclastesis (Wetzel and Einsele, 1991; Canton et al., 2001), are probably able to produce such tubular fabrics that are later impregnated by Fe-oxides. Actually, the cross hatched pattern in Figure (5e) might be comparable to the rhombic organisation in Figure (2h). This speculation would be considerably more reliable if one 
considers that such fractures were initiated as microfractures (Cescas et al., 1970; Kranz, 1983; Kishné et al., 2009) and expanded along with the repeated wetting/drying seasons and the concomitant $\mathrm{Fe}$ oxide growth, to result in the present image.

\section{Conclusion}

This article emphasises the similarity of the redoximorphic features created by inorganic processes to those created as bioturbations in mudstones. It is evident that the variations in paleoclimatic conditions have led to striking differences in the physical fabric of the clay-rich sediments. The tubular forms of iron oxides are exceptionally manifest in the mudstone, which obviously preserves greater degrees of redox mottling and intensity of the dehydration fractures. The proliferation of these abiotic pedogenic features, compared to those of other mudstones, reflects and records the influence of relatively more repetitive 'wetting/drying' seasons. Therefore, this suggests that subtropical paleoclimatic depositional conditions prevailed in the area during the Late Eocene.

Emphasis on the recognition of the physical fabric of mudstones will not only help in predicting paleoclimate but also in reducing the risk of geological misinterpretation. Since the physical fabric could lead to the production of redox patterns resembling those of the biogenic fabric, the spontaneous interpretation of tubular redoximorphic features in mudstones as trace fossils is not necessarily correct. Being aware of the ubiquity and patterning of the physical paleo-pedogenic features will certainly help in avoiding erroneous interpretations. Additionally, by attributing the occurrence of these features to the influence of climatic conditions, physical redoximorphic features become a very useful tool for recognising emersion surface sequence boundaries.

\section{Acknowledgments}

Thanks firstly go to program PAUSE for the financial support of a research job for Mr. Abouessa at University of Strasbourg, and for the University of Strasbourg (UDS/EOST) for the adoption of the study Project. Special thanks go to M. Schuster for his very critical and exciting comments. J.-F. Ghienne's contribution was, as well, very constructive. Finally, the corrections provided by the reviewers to improve the manuscript are highly appreciated, those made by M. Alfred Uchman are greatly refined the original version.

\section{References}

Abouessa, A., Pelletier, J., Duringer, Ph, Schuster, M., Schaeffer Ph., Métais, E., Benammi, M., Salem, M., Hlal, O., Brunet, M., Jaeger, J.-J., Rubino, J.-L., 2012. New insight into the stratigraphy and sedimentology of the Dur At Talah escarpment (Eocene-Oligocene, Sirt Basin, Libya). Journal of African Earth Sciences 65, 72-90.

Abouessa, A., Duringer, Ph, Schuster, M., Pelletier, J., 2015. Crayfish fossil burrows, a key tool for identification of terrestrial environments in tide-dominated sequence, Upper Eocene, Sirt Basin, Libya. Journal of African Earth Sciences 111, 335-348.

Ambrosi, J.P., Nahon, D., 1986. Petrological and geochemical differentiation of lateritic iron crust profiles. Chemical Geology 57, 371-398.

Arshad, M.A., Arnaud, R.J., 1980. Occurrence and characteristics of ferromanganiferous concretions in some Saskatchewan soils. Canadian Journal of Soil Sciences 60, 685-695. 
Barge, L.M., Hammond, D.E., Chan, M.A., Potter, S., Petrusk, J., Nealson, K.H., 2011. Precipitation patterns formed by self-organizing processes in porous media. Geofluids 11, 124-133.

Barge, L.M., Cardoso, S.S., Cartwright, J.H., Doloboff, I.J., Flores, E., Macías-Sánchez, E., Sainz-Díaz, C.I., Sobrón, P., 2016. Self-assembling iron oxyhydroxide/oxide tubular structures: laboratory-grown and field examples from Rio Tinto. Proceedings of the Royal Society 472, 1-19.

Beverly, E.J., Lukens, W.E., Stinchcomb, G.E., 2018. Paleopedology as a Tool for Reconstructing Paleoenvironments and Paleoecology. D.A. Croft et al. (eds.): Methods in Paleoecology: Reconstructing Cenozoic Terrestrial Environments and Ecological Communities, Vertebrate Paleobiology and Paleoanthropology p 151-183.

Bland, W., Rolls, D., 1998. Weathering - An introduction to the scientific principles. Arnold Publishers, London, $280 \mathrm{p}$.

Brewer, R., 1976. Fabric and Mineral Analysis of Soils. Krieger Publ. Co., Huntington, New York. 482 p.

Brierley, J.A., Stonehouse, H.B., and Mermut, A.R., 2011. Vertisolic soils of Canada: Genesis, distribution, and classification. Canadian Journal of Soil Sciences 91, 903-916.

Bromley, R.G., Frey, R.W., 1974. Redescription of the trace fossil Gyrolithes and taxonomic evaluation of Thalassinoides, Ophiomorpha and Spongeliomorpha. Bulletin of Geological Society of Denmark 23, 311-335.

Bouma, J.A., Jongerius, A., Boersma O., Jagger, A., 1977. The function of different types of macropores during saturated flow through four swelling soil horizons. Soil Science Society of America Journal 41, 945-950.

Breemen, V.N., Buurman, P., 2002. Soil Formation, Second Edition, 404 P.

Buatois, L.A., Mángano, M.G., 2004. Animal-substrate interactions in freshwater environments: applications of ichnology in facies and sequence stratigraphic analysis of fluvio-lacustrine successions. Geological Society of London, Special Publications 228, 311-333.

Buurman, P., 1975. Possibilities of paleopedology. Sedimentology 22, 289-298.

Cescas, M.P., Tyner, E.H., Harner, R.S., 1970, Ferromanganiferous soil concretions: A scanning electron microscope study of their micropore structures. Soil Science Society of America Proceedings 34, 641-644.

Chaosheng Tang, Yu-Jun Cui, Bin Shi, Anh Minh Tang, Chun Liu, 2011. Desiccation and cracking behavior of clay layer from slurry state under wetting-drying cycles. Geoderma 166, 111-118.

Chan, M.A., Ormö, J., Park, A.J., Stich, M., Souza-Egipsy, V., Komatsu, G., 2007. Models of iron oxide concretion formation: field, numerical, and laboratory comparisons. Geofluids, 7, 356-368.

Duchaufour, P., 1982, Pedology: London, George Allen \& Unwin Ltd., 448 p.

Dasog, G.S., Acton, D. F., Mermut, A. R. and de Jong, E., 1988. Shrink-swell potential and cracking in clay soils of Saskatchewan. Canadian Journal of Soil Sciences 68, 251-260.

Driese, S.G., Foreman, J.L., 1992, Paleopedology and paleoclimatic implications of late Ordovician vertic paleosols, Juniata formation, southern Appalachians: Journal of Sedimentary Petrology 62, 71-83.

Driese, S.G., Simpson, L.E., Erikson, A.K, 1995. Redoximorphic paleosols in alluvial and lacustrine deposits, 1.8 GA Lochnes Formation, Mount Isa, Australia: pedogenic processes and implications for paleoclimate. Journal of Sedimentary Research A65, 675-689.

Driese, S.G., Mora, C.I., Stiles, C.A., Joeckel, R.M., Nordt, L.C., 2000. Mass-balance reconstruction of a modern Vertisol: implications for interpreting the geochemistry and burial alteration of paleo-Vertisols. Geoderma 95, 179-204.

Einsele. G., 1983. Mechanismus und Tiefgang der Verwitterung bei mesozoischen Ton-Mergelsteinen. Zeitschrift der Deutschen Geologischen Gesellschaft 134, 289-315. concretions in an imperfectly drained Alfisol. Proceedings of 9th Panhellenic Soil Congress, Hellenic Soil Science Society 1, 527-535.

Gasparatos D, Haidouti C, Tarenidis D., 2004. Characterization of iron oxides in Fe-rich concretions from an imperfectly drained Greek soil: a study by selective-dissolution techniques and X-ray diffraction. Archives of Agronomy and Soil Science 50, 485-493.

Gasparatos, D., 2012. Fe-Mn Concretions and Nodules to Sequester Heavy Metals in Soils. Lichtfouse, E., Schwarzbauer, J., Robert, D. (eds.): Environmental Chemistry for a Sustainable World 2, 444-474.

Genise, J.F., Bellosi, E.S., Gonzalez, M.G., 2004. An approach to the description and interpretation of ichnofabrics in paleosols. In: McIlroy, D. (ed.): The Application of Ichnology to Palaeoenvironmental and Stratigraphic Analysis. Geological Society of London, Special Publications 228, 355-382.

Gregory, M.R., Martin, A.J., Campbell, K.A., 2004. Compound trace fossils formed by plant and animal interactions: Quaternary of northern New Zealand and Sapelo Island, Georgia (USA). Fossils and Strata 51, 88105.

Goldenfeld, N., Chan, P.-Y., Veysey, J., 2006. Dynamics of precipitation pattern formation at geothermal hot springs. Physical Review Letters 96, 254-501.

Hasiotis, S.T., 2002. Continental Trace Fossils. SEPM, Short Course Notes Number 51, Tulsa, Oklahoma. 132 p. 
Hasiotis S.T., Mitchell C.E., 1993. A comparison of crayfish burrow morphologies: Triassic and Holocene fossil, paleo- and neo-ichnological evidence, and the identification of their burrowing signatures. Ichnos, 2, 291-314.

Hasiotis, S.T., Bourke, M.C., 2006. Continental trace fossils and museum exhibits: displaying burrows as organism behaviour frozen in time. Geological Curator 5, 211-226.

Hildenbranda, A., Uraib, J.L., 2003. Investigation of the morphology of pore space in mudstones - first results. Marine and Petroleum Geology 20, 1185-1200.

Howard, J.D. Frey, R.W., 1984. Characteristic trace fossils in nearshore to offshore sequences, Upper Cretaceous of east-central Utah. Canadian Journal Earth Science 21, 200-219.

Jaeger, J.J., Marivaux, L., Salem, M., Bilal, A.A., Benammi, M., Chaimanee, Y., Duringer, Ph., Marandat, B., Métais, E., Schuster, M., Valentin, X., Brunet, M., 2010a. New rodent assemblages from the Eocene Dur AtTalah escarpment (Sahara of central Libya): systematic, biochronological, and Palaeobiogeographical implications. Zoological Journal of Linnean Society 160, 195-213.

Jaeger, J.J., Beard, K.C., Chaimanee, Y., Salem, M.J., Benammi, M., Hlal, O., Coster, P., Bilal, A.A., Duringer, Ph., Schuster, M., Valentin, X., Marandat, B., Marivaux, L., Métais, E., Hammuda, O., Brunat, M., 2010b. Late middle Eocene epoch of Libya yields earliest known radiations of African anthropoids. Nature 467, 1095-1099. Jaillard, B., Guyon, A. and Manrin, A.F., 1991. Structure and composition of calcified roots and their identification in calcareous soils. Geoderma, 50, 197-210.

Kessler, M.A., Werner B.T., 2003. Self-organization of sorted patterned ground. Science 299, 380-383.

Kishné, A. Sz., Morgan, C.L.S., Miller, W.L., 2009. Vertisol Crack Extent Associated with Gilgai and Soil Moisture in the Texas Gulf Coast Prairie. Soil Science Society of America Journal 73, 1122-1231.

Klappa, C.F., 1980, Rhizoliths in terrestrial carbonates: classification, recognition, genesis, and significance: Sedimentology 26, 613-629.

Kovda, I., Goryachkin, S., Lebedeva, M., Chizhikova N., Kulikov, A., Badmaev, N., 2017. Vertic soils and Vertisols in cryogenic environments of southern Siberia, Russia, Geoderm 288, 184-195.

Kraus, M.J., 1998, Development of potential acid sulfate paleosols in Paleocene floodplains, Bighorn Basin, Wyoming, USA: Palaeogeography, Palaeoclimatology, Palaeoecology 144, 203-224.

Kraus, M.J., Aslan, A., 1993. Eocene hydromorphic paleosols: significance for interpreting ancient floodplain processes. Journal of Sedimentary Petrology 63, 453-463.

Kraus, M.J., Hasiotis, S.T., 2006. Significance of different modes of rhizolith preservation to interpreting paleoenvironmental and paleohydrologic settings: examples from Paleogene paleosols, Bighorn Basin, Wyoming, U.S.A. Journal of Sedimentary Research 76, 633-646.

Li, J.H., Zhang, L.M., Wang, Y., Fredlund, D.G., 2009. Permeability tensor and representative elementary volume of saturated cracked soil. Canadian Geotechnical Journal 46, 928-942.

Manceau, A., Drits, V.A., Lanson, B., Chateigner, D., Wu. J., Huo, D., Gates, W.P., Stucki, J.W., 2000. Oxidation reduction mechanism of iron in dioctahedral smectites. II. Crystal chemistry of reduced Garfield nontronite. American Mineralogist 85, 153-172.

Mack, G.H., James, W.C., Monger, H.C., 1993, Classification of paleosols: Geological Society of America Bulletin 105, 129-136.

Miller, W.L., Kishne, A.S., Morgan, C.L., 2010. Vertisol morphology, classification, and seasonal cracking patterns in the Texas Gulf coast prairie. Soil Horizons 51, 10-16.

Moh, H.H., Chong, V.C., Sasekumar, A., 2015. Distribution and burrow morphology of three sympatric species of Thalassina mud lobsters in relation to environmental parameters on a Malayan mangrove shore. Journal of Sea Research, 95, 75-83.

Monaco. P., 2000. Decapod burrows (Thalassinoides, Ophiomorpha) and crustacean remains in the Calcari Grigi, Lower Jurassic, Trento platform (Italy). 1st Workshop on Mesozoic and Tertiary decapod crustaceans (VI), 293-301.

Mondol, N.H., Bjorlykke, K., Jahren, J., 2008. Experimental compaction of clays: relationship between permeability and petrophysical properties in mudstones. Petroleum Geoscience 14, 319-337.

Moussavi-Harami, R., Mahboubi, A., Nadjafi, M., Brenner, R.L., Mortazavi, M., 2009. Mechanism of calcrete formation in the Lower Cretaceous (Neocomian) fluvial deposits, northeastern Iran based on petrographic, geochemical data. Cretaceous Research 30, 1146-1156.

Muller, J.-P., Bocquier, G., 1986. Dissolution of kaolinites and accumulation of iron oxides in lateriticferruginous nodules: mineralogical and microstructural transformations. Geoderma 37, 113-136.

Nascimento, D., L., Batezelli, A., Ladeira, F.S., 2019. The paleoecological and paleoenvironmental importance of root traces: plant distribution and topographic significance of root patterns in upper cretaceous paleosols. Catena 172, 789-806.

Ollier, C.D., 1971. Causes of spheroidal weathering. Earth-Sciences Reviews 7, 127-141.

Pipujol, M.D., Buurman, P., 1994. The distinction between ground-water gley and surface-water gley phenomena in Tertiary Paleosols of the Ebro Basin, NE Spain: Palaeogeography, Palaeoclimatology, Palaeoecology 110, 103-113. 
Rayhani, M.H.T., Yanful, E.K., Fakher, A., 2008. Physical modeling of desiccation cracking in plastic soils. Engineering Geology 97, 25-31.

Retallack, G.J., 1983. Late Eocene and Oligocene paleosols from Badlands National Park, South Dakota: Geological Society of America, Special Paper 193, 82 p.

Sadek, S., Sultan, R., 2011. Liesegang patterns in nature: A diverse scenery across the sciences, a review paper, Research Snapshot, 37/661, 1-43.

Schwertmann, U., 1993. Relations between iron oxides, soil colour, and soil formation: Journal of Soil Science 31, 51-69.

Schwertmann, U., Taylor, R.M., 1989. Iron oxides, in Dixon, J.B., Weed, S.B., (eds.): Minerals in Soil Environments. Soil Science Society of America p. 379-438.

Seilacher, A., 2007. Trace fossil analysis. Springer Verlag, Heidelberg, 226 p.

Smith, J.J., Hasiotis, S.T., Woody, D.T., Kraus, M.J., 2008. Paleoclimatic implications of crayfish-mediated prismatic structures in paleosols of the Paleogene Willwood formation, Bighorn basin, Wyoming, U.S.A. Journal of Sedimentary Research 78, 323-334.

Soil Survey Staff, 1998. Keys to Soil Taxonomy, 8th edn. US Government Printing Office, Washington DC, 324 p.

Sridharan, A., Allam, M.M., 1982. Volume change behaviour of desiccated soils. Proceedings of ASCE. Journal of the Geotechnical Engineering Division, 108, 1057-1071.

Thompson, A.E., Stokes, W.L., 1970. Stratigraphy of the San Rafael Group, southwest and south-central Utah. Utah Geological and Mineralogical Survey Bulletin 87, 53 p.

Veneman P.L.M., Vepraskas, M.J., Bouma, J., 1975. The physical significance of soil mottling in a Wisconsin toposequence. Geoderma, 15, 103-118.

Vepraskas, M.J., 1994. Redoximorphic features for identifying aquic conditions: North Carolina Agricultural Research Service, Technical Bulletin 301, 33 p.

Wang, Y., Chan, M.A., Merino, E., 2015. Self-organized iron-oxide cementation geometry as an indicator of paleo-flows. Scientific Report, srep10792, 1-15 p.

Wight, A.W.R., 1980. Paleogene vertebrate fauna and regressive sediments of Dur At Talah, southern Sirt Basin, Libya. In: Salem, M.J., Burwell, M.T. (eds.): The Geology of Libya, vol. I. Academic Press, London, p. 309-325. Yuen, K., Graham, J., Janzen, P., 1998. Weathering-induced fissuring and hydraulic conductivity in a natural plastic clay. Canadian Geotechnical Journal 35, 1101-1108.

Zhang, M., Karathanasis, A.D., 1997. Characterization of iron-manganese concretions in Kentucky alfisols with perched water tables. Clays and Clay Minerals 45, 428-439.

\section{Figure captions}

Fig. 1: Location and geological section; a) map of Libya shows the location of the area of study (the rectangle); b) the representative section of New Idam Unit, shows the position of the mudstone hosting the redoximorphic pedo-turbations; c) outcrop view of the studied mudstone.

Fig. 2: The variations of the mudstone's fractural fabric; a) initial open fractures separating vertical mud blocks; b) disintegration of vertical mud blocks into smaller peds. Circular and semi-cylindrical mud masses was formed (dashed green and orange lines); c) base of large mudstone block shows different generation of cracks; d) initial phases of staining of the mud blocks, Fe-oxide concentrates adjacent to the crack walls (e.g., arrows); e) semi-cylindrical mud mass shows subordinate phase of (horizontal) fracturing; f) aggregated sub- (vertical) fracture with branchings, morphologically comparable to root tracks; g) aggregated (vermicular) network of fractures, imitating bioturbations; h) diagonally intersected short-spaced fractures seen only in the host mud.

Fig. 3: Possibilities of the patterns of the fractures as exhibited by the host mudstone; a) longitudinal, straight and irregular fractures. Control of fractures on redox forms is remarkable in a, b; b) similar representation of the redox feature in a different manner; $\mathrm{c}, \mathrm{d}$ ) image and drawing illustrate the circular cracks dominated the lower reaches of the bed; e) composite straight and circular fractures producing/separating subcircular masses of variable sizes, internal concentric rings; f) vermicular fabric, caused by the combination of fractures and mud aggregation. Scale bar: a, b $5 \mathrm{~cm}$; c, d and e 2 $\mathrm{cm}$; $1.5 \mathrm{~cm}$. 
Fig. 4: The appearance of the studied structures in the outcrop; a, b) general views shows-the change from crowded network of small tubules to larger shafts below (inconsistent with roots); c-f) shafts from different locations but of the same horizontal level, unambiguously oriented parallel. Excavation/penetration cannot not be proven in these forms. The brown Fe-oxides engulf physically intact mudstone masses. Lines highlight parallelism. In the images (c) and (e) the scale is the finger and the hand respectively.

Fig. 5: The occurrence pattern and morphology of the hosted structures; a) wedge shaped rectangular mud block stained/coated by Fe-oxide. Red arrows for slickenside faces, blue arrows point to the initial oxidation spots along fractures; $b, c$ ) differentially pigmented mud blocks, notice the privileged (fracture-controlled) diversion angle (dashed lines). The interior preserves the same fractures as that of the ambient mud; d) semi-tubules within a fractured block, oxidized ones are similar to that which are partially oxidized. The halos in the vicinity, have nearly the same shape, size and more or less orientations, arrow heads point to microfractures that might be in relation. The blue arrows point to the likely descending Fe-oxides growth; e) close-up view of the rectangle in Figure (4b). It shows shortly spaced diagonally attached straight segments (individual tubules), of which the intensity and orientations are comparable to that of the associated cracks (comparable also to the fracture's pattern in Figure (2h). Hammer handle for scale in (b) and (d).

Fig. 6: The irregularly cylindrical-shaped simple and composite vertical forms; a) appearance in the outcrop; b) large tube composed of smaller tubules (comparable to the circular fractures in Fig. 3c-e), another example of such composite shafts is presented by the image (c); d) subvertical cylindrical body with descendant tubular/tabular appendages attached to it, this is shown also in $\mathrm{a}, \mathrm{b}$ (the arrows). Some are not attached (dashed circles in $b, c$ ). The red arrow head points to a tabular, aggregated fracture zone. It is morphologically comparable to the adjacent, long oxidized appendages.

Fig. 7: Practical proof of the physical template-based Fe-oxides morphologies; a, b) image and illustrative sketch suggesting that the precipitation is guided by the concentric cracks (compare Fig. $3 \mathrm{c}-\mathrm{d})$. The arrows point to the incomplete cylindrical growth as guided by the circular fracture. Such arc (arrows) would continue to form (a perfect) vertical tubular body, if the reaction had not been stopped. The same way, regardless of diameter, the completed rings (solid lines) had been originated by overprinting the dashed ones; c) this image proposes an example of the fabrication of tubular forms based on a pre-exist physical (fabric) template. Oxidation (brown) and reduction (gray) occurred adjacently, the fractures are the visible control for the redistribution of the iron oxides. The red dashed lines are for the roughly shaped unoxidized tubes, the solid red lines are for the reshaping by the $\mathrm{Fe}$ oxides growth, black lines point to the fine internal (subordinate) cracks. The general view of the image (c) is the square in Figure (3b); d) subvertical shaft body shows that the Fe-oxide accumulation is supervised by the pre-existed fractures (straight green lines). Further Fe-oxide accumulation would mask these details and would result in a complete cylindrical shape. 


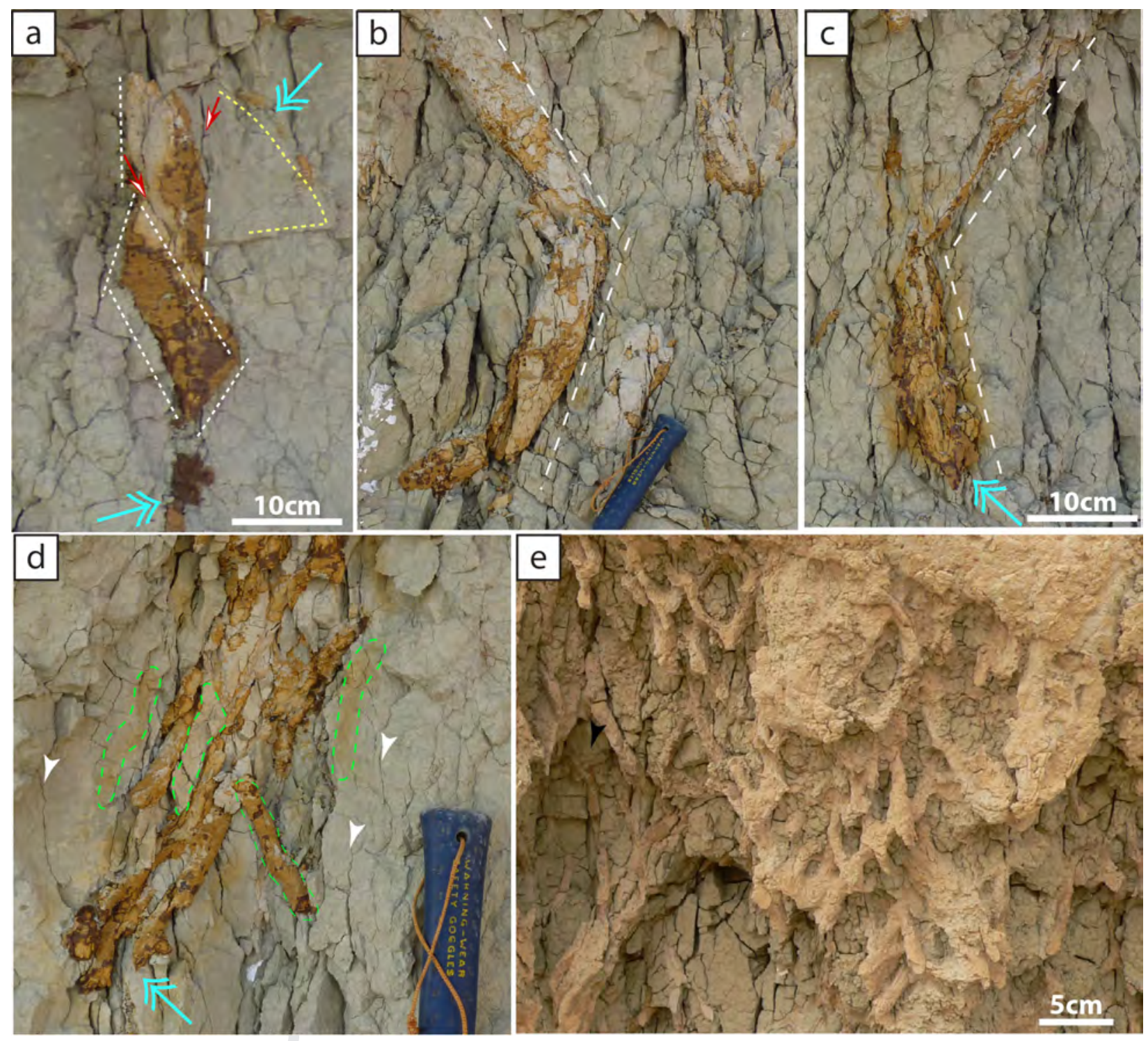



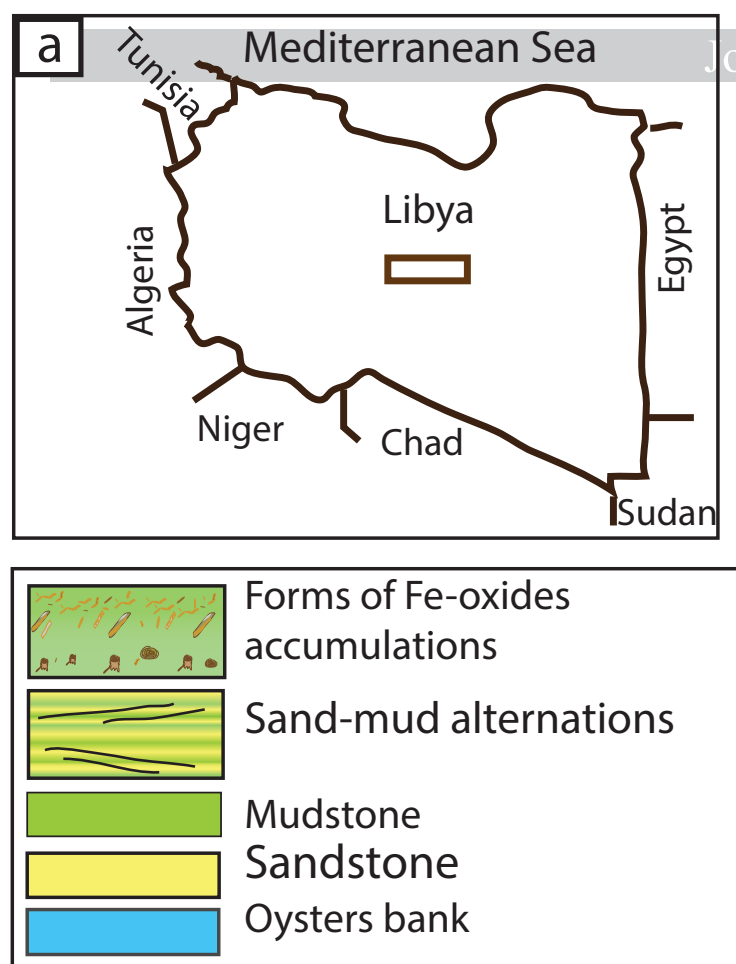

$$
\begin{aligned}
& \text { Forms of Fe-oxides } \\
& \text { accumulations } \\
& \text { Sand-mud alternations } \\
& \text { Mudstone } \\
& \text { Sandstone } \\
& \text { Oysters bank }
\end{aligned}
$$

Thalassinoides

Fossil fish

_ Vertebrate bones I

Silicified wood U

$\approx$ Plant debris

ᄀ Fossil root traces
Cylindrical burrow Skolithos isp, Diplocraterion isp Erosional surface $=$ Laminations $=$ Ripple cross lam.

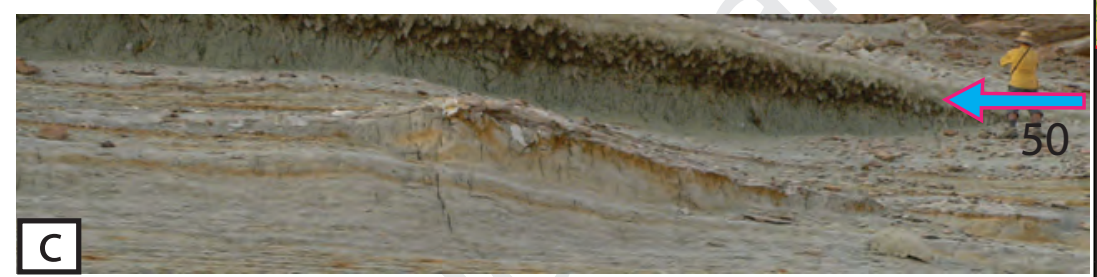

70

65

75

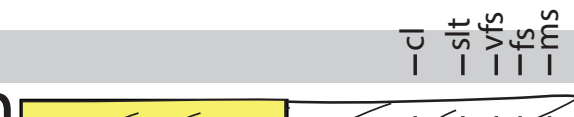

\section{.}

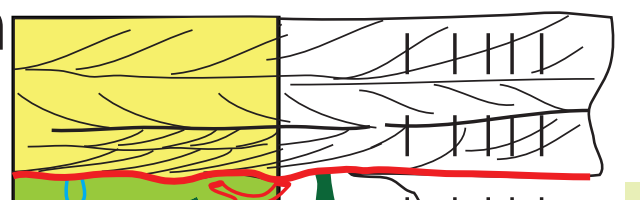

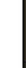

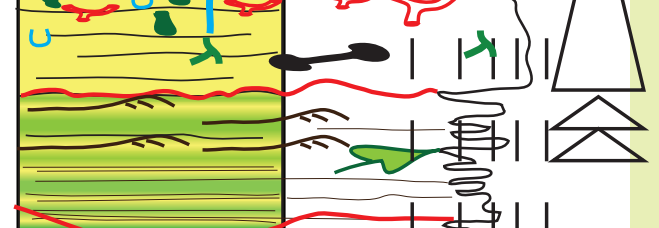

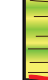

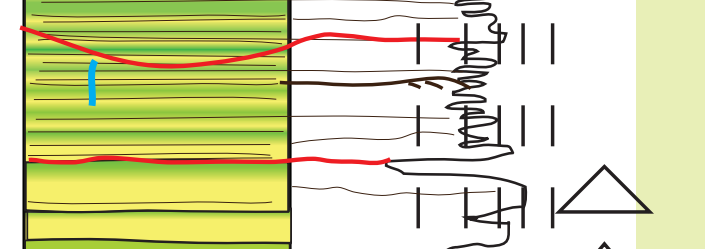

60

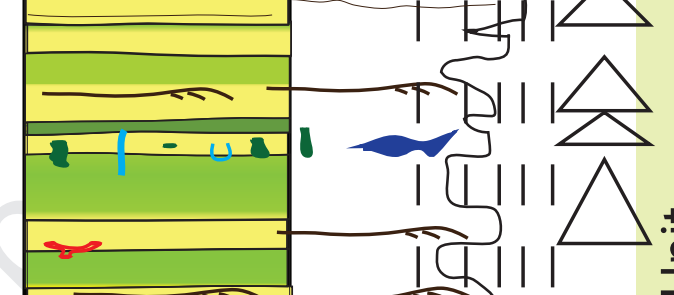

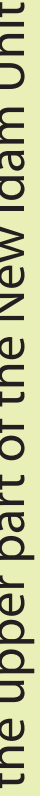

45

40

35
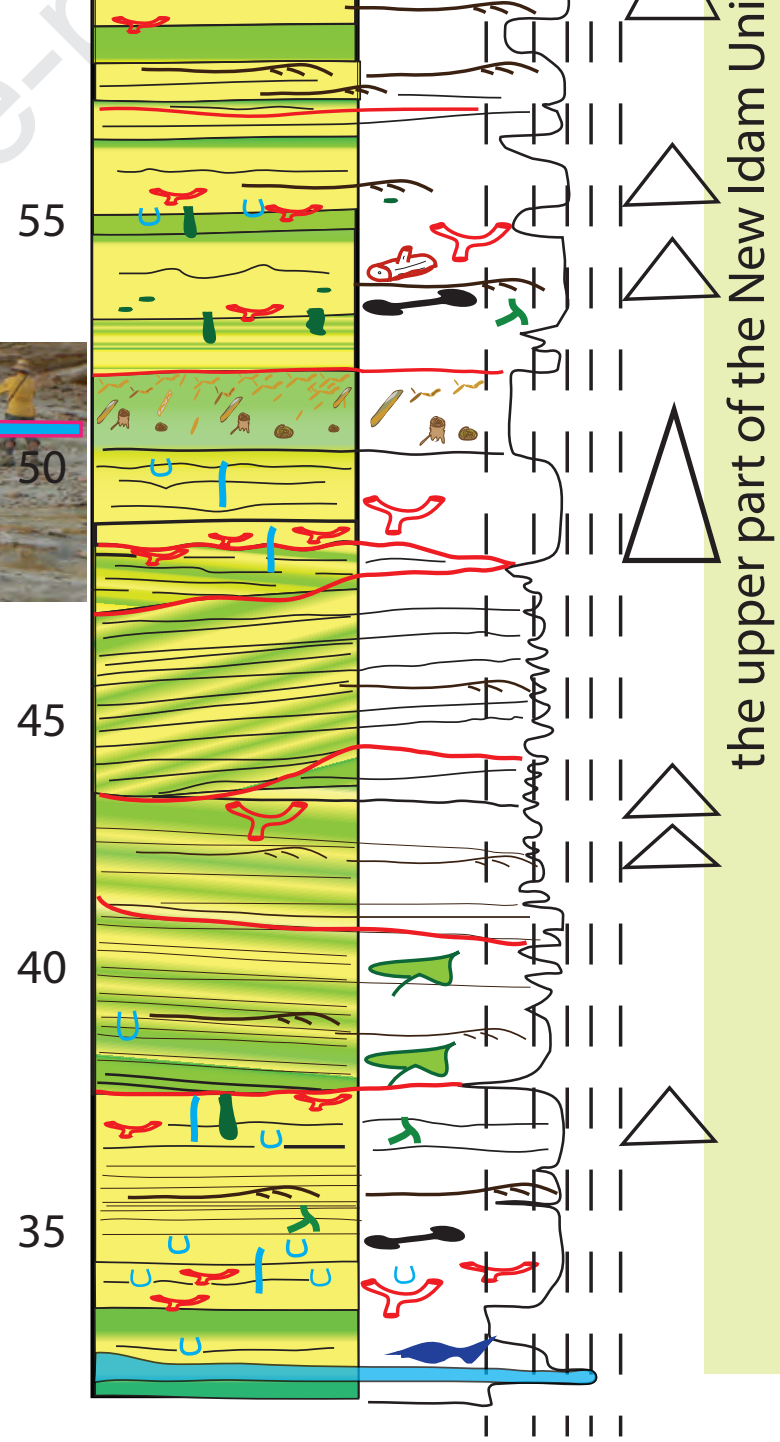

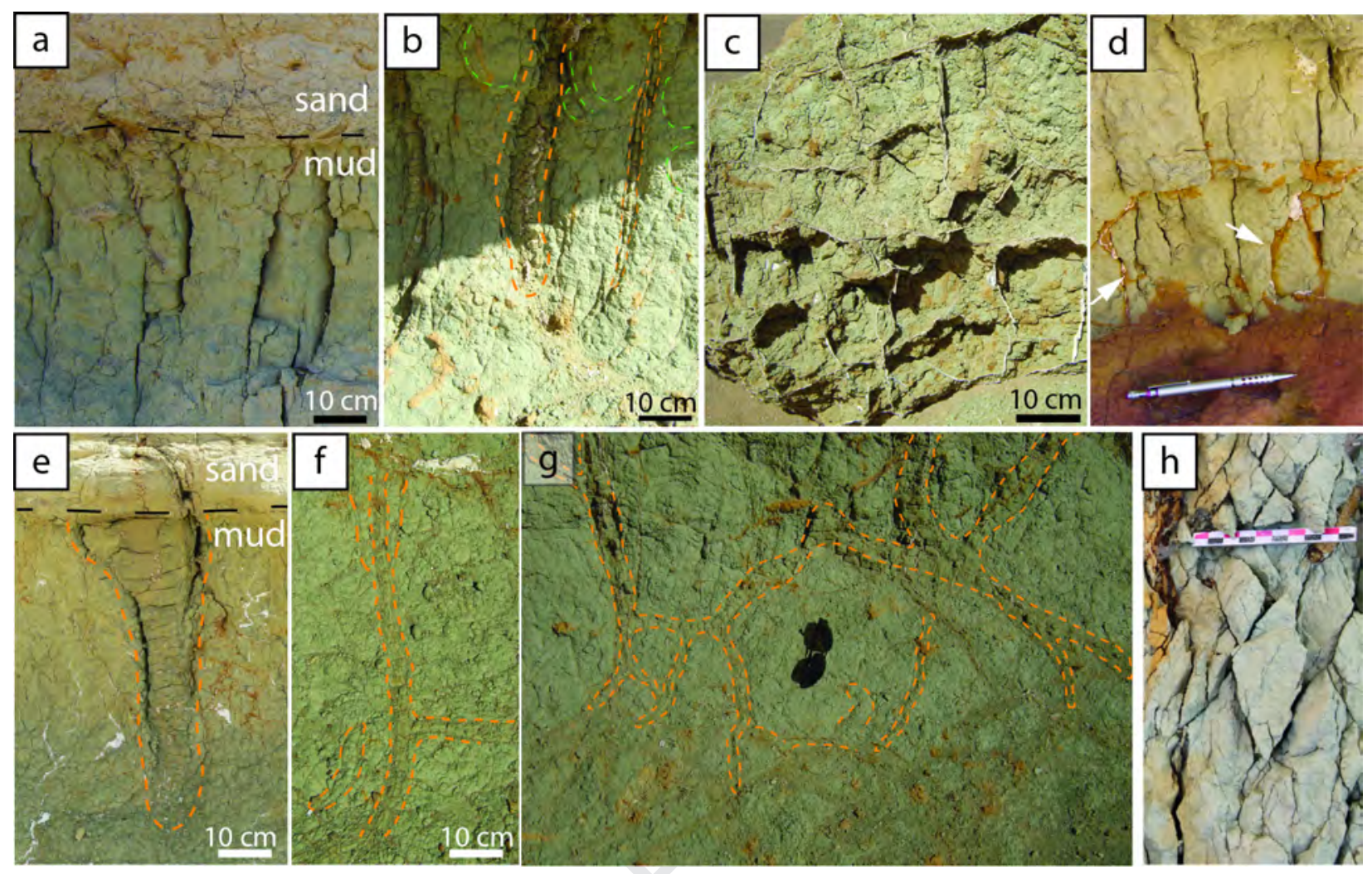

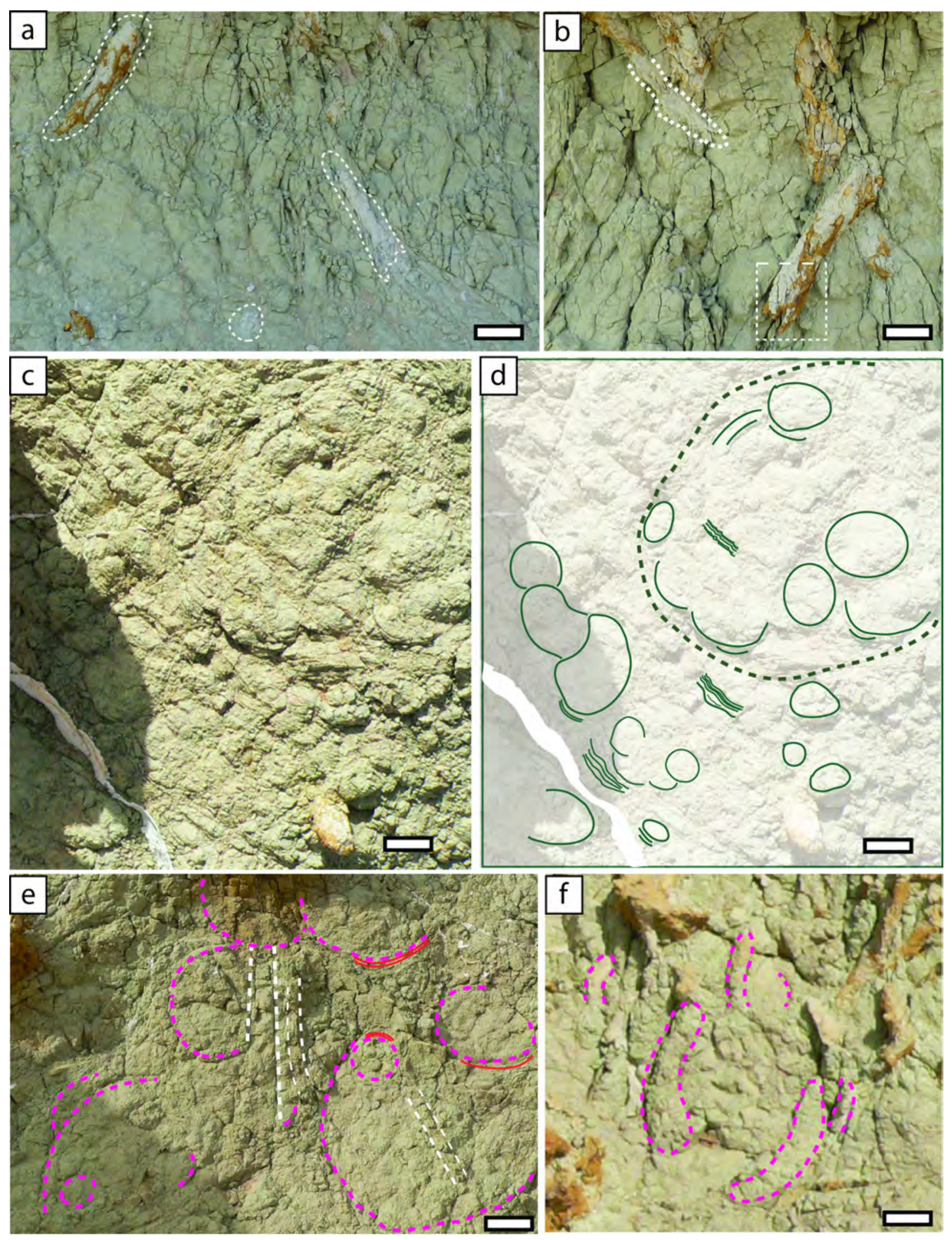

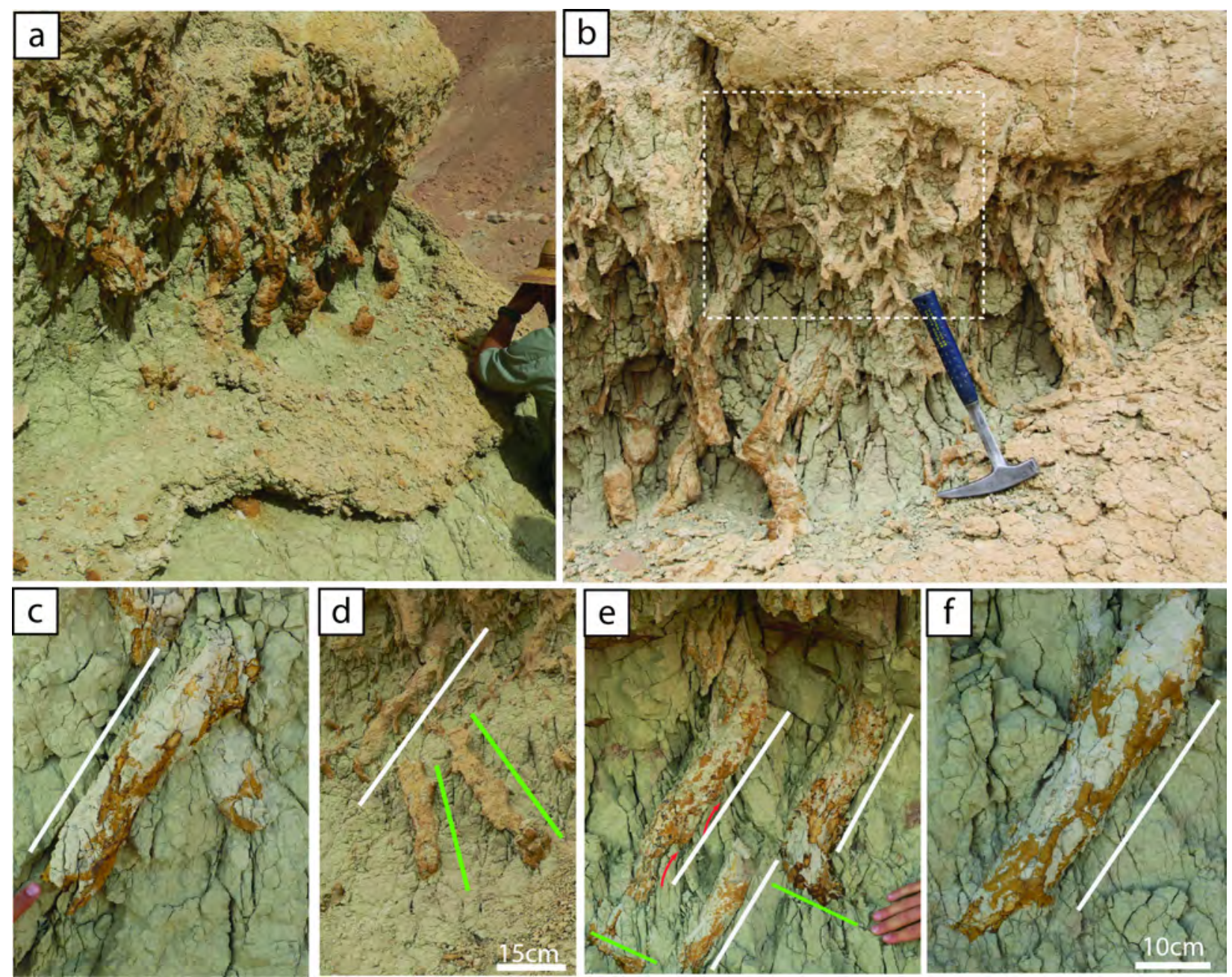

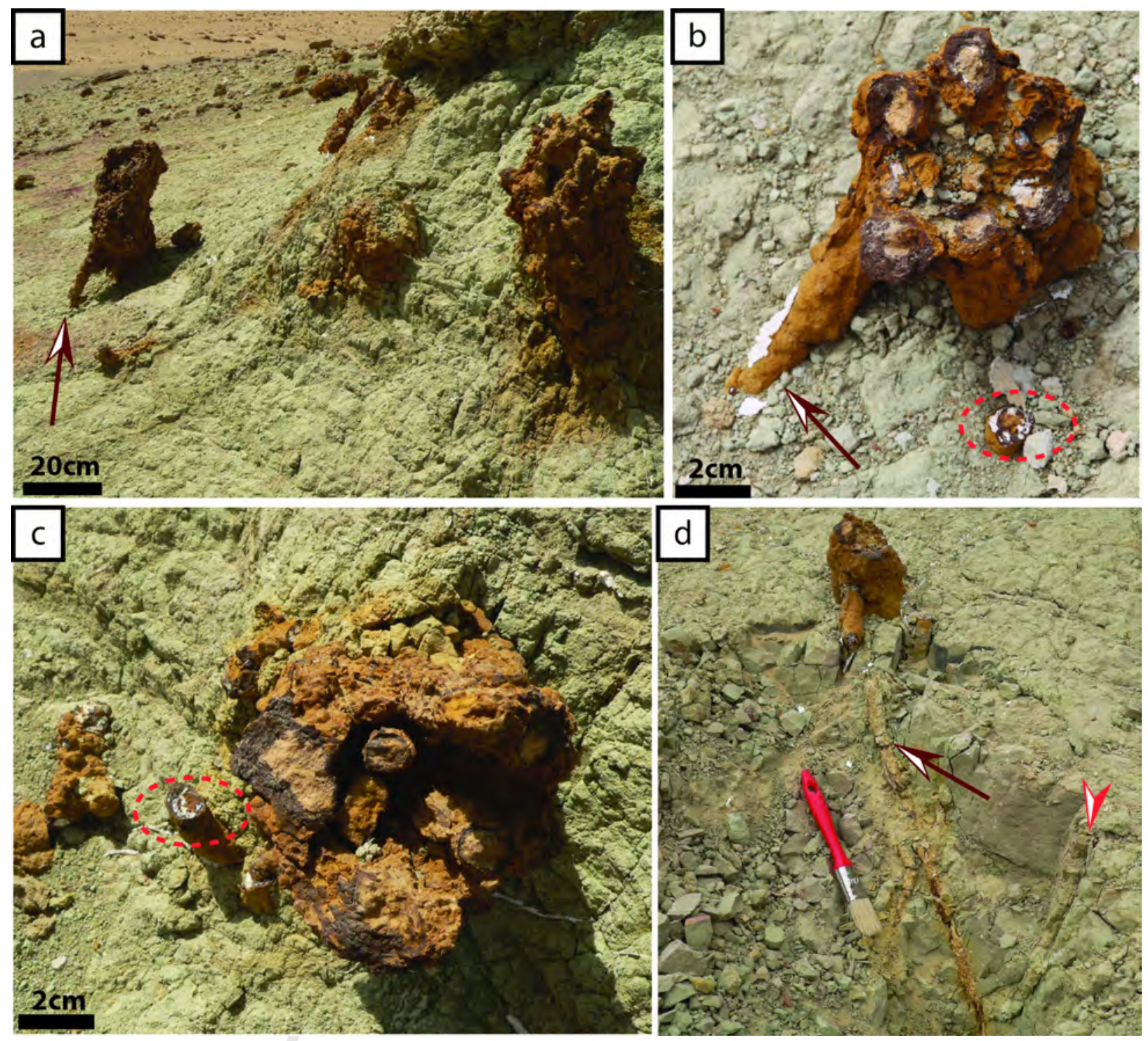


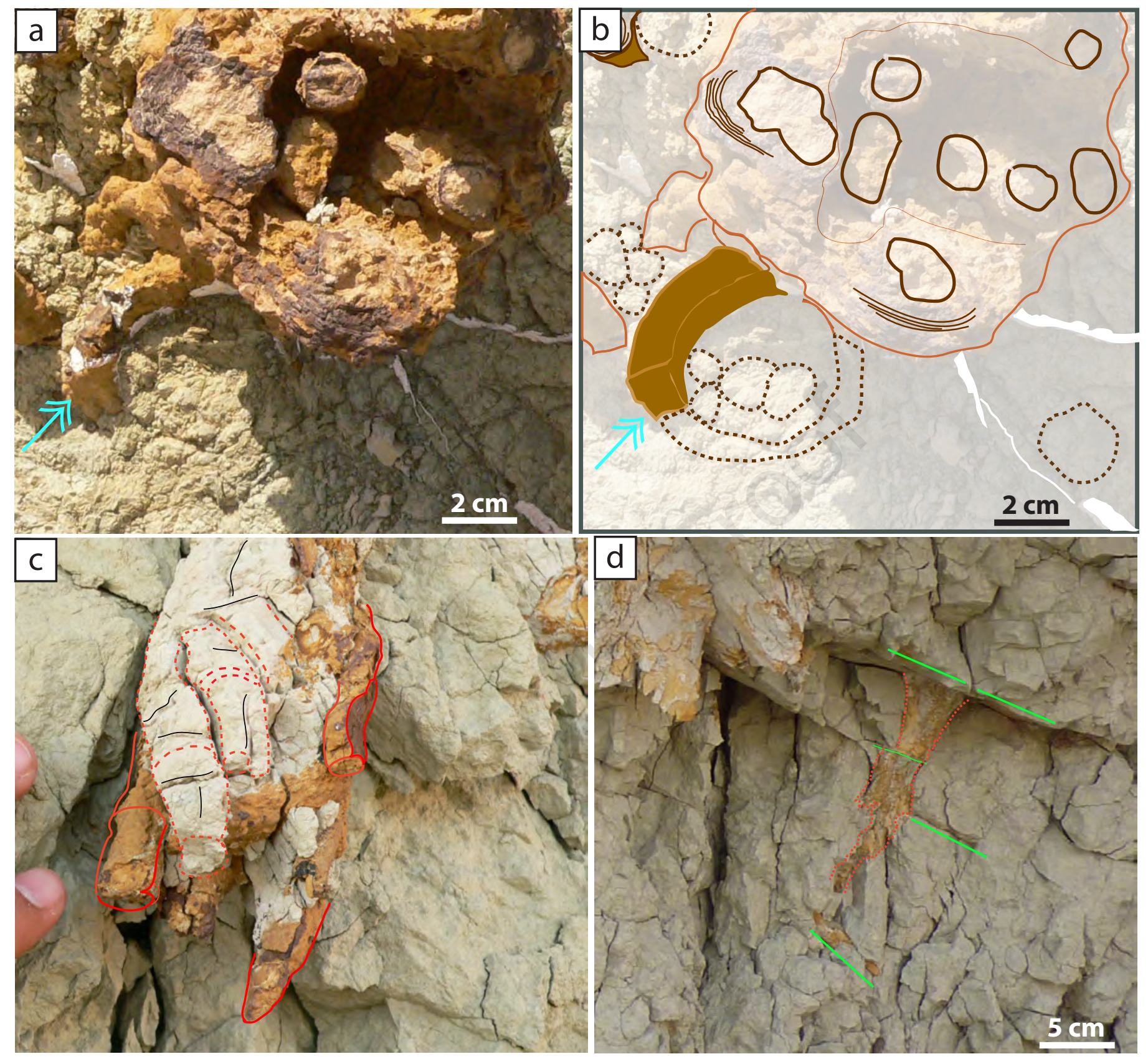




\section{$\underline{\text { Highlights }}$}

- Mudstone's physical fabric creates trace fossil-like features

- The recognition criteria of paleosols are useful as indicators of paleoclimate

- Redox processes in paleosols may cause misleading geological interpretation

- Subaerial exposure in the Eocene of Sirt basin indicated by pedogenic structures 


\section{Declaration of interests}

The authors declare that they have no known competing financial interests or personal relationships that could have appeared to influence the work reported in this paper.

$\square$ The authors declare the following financial interests/personal relationships which may be considered as potential competing interests:

Dr. Ashour Abouessa on behave of the authors

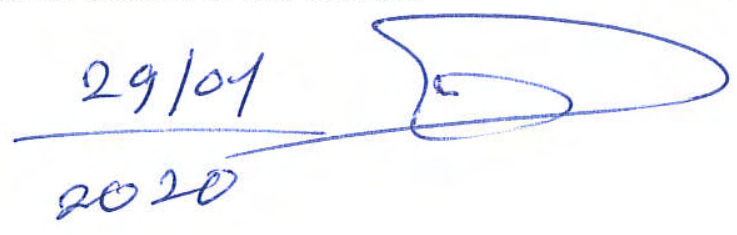

